\title{
Wallaces' Farmer's Crusade against Rural Crime in the 1920s
}

\section{DOUglas Wertsch}

"CHICKEN" WILSON and "Whitey" Lime, two farm thieves, had their pictures in the paper. Next to them on the page was a photograph of their captor, Woodbury County Sheriff Paul T. Beardsley. Beardsley was receiving acclaim from Wallaces' Farmer for clever detective work in his "clean-up" of farm thieves in his county. ${ }^{1}$ The normally conservative farm paper was beginning to read like a detective novel. Subscribers were being regaled with stories about crime - not distant urban crime, but chicken theft, fraud, and burglaries in their own communities. Wallaces' Farmer was conducting a crusade.

The crusade arose from a combination of pragmatic business considerations and rural circumstances new to the 1920s. As businessmen, the editors of Wallaces' Farmer knew increased circulation meant increased profits. If they could identify and provide a unique service to their subscribers, the farm journal's circulation and profits would increase. The new rural circumstances of the 1920 s, especially rural prosperity and the good roads that developed between 1910 and 1920, generated the conditions that made it possible to identify such a service. Prosperity meant that many farmers had money, while the good roads that provided easy access to market also brought an unprecedented host of thieves and bunko artists to the farmer's property and mailbox. ${ }^{2}$ At the same

1. Wallaces' Farmer, 25 February 1927.

2. Bruce Smith, Rural Crime Control (New York, 1933), 3-4. For a discussion of other conditions prevailing in rural lowa during the 1920s, see Leland L. Sage, "Rural lowa in the 1920s and 1930s: Roots of the Farm Depression," Annals of lowa 47 (Fall 1983), 91-103; and Joseph Frazier Wall, "The lowa Farmer in Crisis, 1920-1936," ibid., 116-27. For an excellent discussion of the quandary rural lowans faced in the 1920s, see Dorothy Schwieder, "Rural Iowa in the 1920s: Conflict and Continuity," ibid., 104-15.

THE ANNALS OF IOWA 50 (Spring 1990). (C) The State Historical Society of Iowa, 1990. 
time, a larger "crime wave" was capturing the attention of the state and national press. Wallaces' Farmer's crusade both reflected and capitalized on this awareness. By focusing its readers' attention on rural incidents of crime, the farm paper combined those elements of calculated self-interest and genuine altruism so typical of American crusades.

The paper's editor, Henry Agard Wallace, bucked the national progressive trend of forming "blue ribbon" crime commissions to study the problem. He chose instead to rely on an older American tradition: forming voluntary citizen-cooperatives to solve problems. Twice he considered and dismissed a proposal that smacked of progressivism - a proposal to establish a state police force. When he did agitate for state involvement, it was for legislation, not police.

Wallace's crusade unfolded incrementally. Beginning in 1921 with an initial awareness of the scope of the problem, Wallace explored various alternatives until 1924. At that time, he and assistant editor William E. Drips launched a full-fledged but focused campaign to encourage the formation of protective associations. In 1926 and 1927 the journal got more directly involved in the campaign by offering rewards itself and by lobbying for legislation. By the end of 1927, when all the fundamental elements of the campaign were in place, the crusade had already had considerable effect on the war on rural crime.

WALLACE'S AWARENESS of the rural crime predicament began shortly after he assumed the journal's editorship on March 4, 1921. ${ }^{3}$ He did not have to look far to find an example of the unique service his paper would soon provide. For three years the

3. Wallaces' Farmer, 11 March 1921. On Wallaces' Farmer and its editor, see Richard S. Kirkendall, "The Mind of a Farm Leader," Annals of Iowa 47 (Fall 1983), 138-53; idem, "Henry A. Wallace's Turn Toward the New Deal, 19211924," Annals of lowa 49 (Winter/Spring 1988), 221-39; Don S. Kirschner, "Henry A. Wallace as Farm Editor," American Quarterly 17 (Summer 1965), 187-202; Edward L. Schapsmeier and Frederick H. Schapsmeier, Henry A. Wallace of Iowa: The Agrarian Years, 1910-1940 (Ames, 1968), 82-94; idem, "A Prophet in Politics: The Public Career of Henry A. Wallace," Annals of lowa 39 (Summer 1967), 1-21; idem, "Henry A. Wallace: Agrarian Idealist or Agricultural Realist?" Agricultural History 41 (April 1967), 127-37; Malcolm O. Sillars, "Henry A. Wallace's Editorials on Agricultural Discontent, 1921-1928," Agricultural History 26 (October 1952), 132-40. 
Prairie Farmer, an Illinois farm journal, had been giving financial advice and warning subscribers about stock frauds; and the Chicago-based Orange Judd Farmer had been running a column entitled "Our Service Bureau" since 1913." In 1912 Wallace's father had printed a reader's request for information about protective associations and later published the responses, but he did not follow up on the suggestions. ${ }^{5}$

H. A. Wallace revived the idea on June 3, 1921, when he announced the formation of a new department in his farm journal. Named the Service Bureau, the department acted as a consumer advocate and as an intermediary between companies that advertised in Wallaces' Farmer and its subscribers. The service was not free. For a minimum three-year subscription, each member of the Service Bureau received a membership certificate and a sign. "This sign," claimed Wallace, "will protect you from fake agents." The sign, not coincidentally, was also free advertising for the farm journal. ${ }^{6}$

The Service Bureau acted at first as a subscribers' information clearing house. The bureau's columns treated topics as diverse as hog-tight fences and state traffic laws. The Service Bureau also offered consumer advice and intervened in cases of fraud. The bureau was often successful in obtaining refunds for its members, especially those dissatisfied with mail-order products. During the first six months of 1923 its personnel secured between fifteen hundred and two thousand dollars monthly in refunds for subscribers. Refunds commonly came from makers of quack home remedies or perpetrators of mail fraud, such as phony stock market sales representatives and farm produce buyers. Other mail frauds publicized by the bureau ranged from work-at-home schemes such as knitting and envelope addressing to solicitations for aid to ill war veterans.?

During the early 1920s Wallace became more aware of the growing rural crime problem. Iowa experienced a sudden and significant increase in identified criminal activity in the 1920 s.

4. James F. Evans, Prairie Farmer and WLS: The Burridge D. Butler Years (Urbana, IL, 1969), 77.

5. Wallaces' Farmer, 27 December 1912, 7 February 1913.

6. Wallaces' Farmer, 3 June 1921.

7. Wallaces' Farmer, 24 August 1923. 
Between 1920 and 1925 the state's total rate of convictions increased from 3.81 to 5.57 per one thousand population, and the conviction rate in Iowa's twenty-one most rural counties nearly doubled from 2.29 to 4.50 during the same period. ${ }^{8}$

The dramatic events surrounding the rural bank robberies that occurred in the 1920s could not have escaped Wallace's attention. In 1919 there were no reported bank robberies and only one unsuccessful bank burglary in lowa. The next year, that situation began to change drastically. In 1920 five banks, all but one of them in rural districts, reported robberies; there were also twenty-five successful and twenty-three unsuccessful rural bank burglaries. Then, during the last six months of 1922, twenty-eight bank robberies occurred in Iowa. In response to this growing problem, bankers organized 3,484 lowans into vigilante groups in 726 towns in seventy-eight counties, and armed them with weapons purchased from the War Department. For a cost of $\$ 48,385.23$ to arm and otherwise equip the vigilante force, the bankers quickly achieved their goal. One year after the vigilantes began operating, only three successful and eight unsuccessful bank robberies took place in the state. In addition, six would-be bank robbers had been shot to death. ${ }^{9}$

William E. Drips, Wallace's Service Bureau editor, doubtless contributed to Wallace's increasing awareness of rural crime. Drips taught journalism at Iowa State College in Ames between 1920 and 1923. His position must have heightened his awareness of the press's unprecedented nationwide emphasis on crime stories. Iowa's largest daily newspaper, the Des Moines Register, had been routinely publishing front-page crime stories since the spring of 1919. In response to such press coverage, several states

8. Charles N. Burrows, "Criminal Statistics in Iowa," University of lowa Studies in the Social Sciences 9, no. 2 (1 July 1930), 106-9. The twenty-one counties were Adair, Adams, Allamakee, Audubon, Chickasaw, Davis, Franklin, Hancock, Iowa, Kossuth, Lyon, Madison, Monona, Monroe, Osceola, Pocahontas, Ringgold, Shelby, Van Buren, Winneshiek, and Worth.

9. Proceedings of the Thirty-third Annual Convention of the lowa Bankers Association: 1919, 224-25; ibid., 1921, 168-72; ibid., 1923, 196, 197. See also Howard H. Preston, History of Banking in lowa (Iowa City, 1922), 375; lowa Homestead, 1 October 1925; and R. C. Saunders, "Organized Protection Against Organized Predatory Crimes," lowa Sheriff 5 (April 1933), 1-3. Burglaries involve breaking into a building with the intent to steal; robberies involve the theft of personal property by violence or threat of violence. 
and two presidents established crime commissions in the 1920s. ${ }^{10}$ Once Wallace was aware of the growing rural crime problem, he began reporting rural developments and encouraging rural lowans to take action. Rural lawmen, who were "admittedly failing to cope with the situation," were easy targets of Wallace's indignation. Conditions had become so bad that Wallace suggested the possibility of protecting farms with local committees of farmer-vigilantes equipped with shotguns. ${ }^{11}$

While he was exploring alternatives, Wallace tentatively proposed establishing a state police. In an editorial, he noted the "increasing amount of thievery" in the rural districts, and a "renewed interest in the subject of a state police." He was not, however, seriously advocating the formation of a permanent statewide program; he was merely trying to get the attention of the state's existing law enforcement officials, especially local, rural officers. Wallace's ambivalence regarding state police was plain. The expense to the state worried him, as did the use of such police in other states to grapple with industrial troubles rather than rural crime. So he did not ardently advocate this solution; nor did he strongly support vigilantism at that time. Still, he wrote, "conditions must be changed." He evidently hoped that the alternatives he suggested would be a prod, a means of getting local lawmen to pursue farm thievery cases more vigorously. ${ }^{12}$

10. Information about William E. Drips is available in the William E. Drips Papers, pp-5; box $1 / 2$ in Iowa State University's Special Collections Department. On the increased attention given to crime in American newspapers in the 1920s, see Nathan Douthit, "Police Professionalism and the War Against Crime in the United States, 1920s-1930s," in Police Forces in History, ed. George L. Mosse (Beverly Hills, CA, 1975), 317-18; and Douglas Wertsch, "The Evolution of the Des Moines Police Department: Professionalization and the Decline of Public Disorder Arrests in the Twentieth Century," Annals of lowa 48 (Winter/ Spring 1987), 440.

11. Wallaces' Farmer, 23 February 1923. Contemporaries agreed that rural officers were inadequate crime-fighters. See Bruce Smith, The State Police: Organization and Administration (New York, 1925), 14-22.

12. Wallaces' Farmer, 23 February 1923. Although Wallace apparently did not know it, the state's sheriffs supported the idea of establishing a state police. Number eight of their twelve-point published "Aims and Policies" was "to encourage the state patrol of our paved highways." See "A State Police Force Could Handle this Situation," lowa Sheriff 5 (May 1933), 10. Many Iowans shared Wallace's reservations regarding state police. Not until May 7, 1935, did lowa establish a state police. See David Getting Monroe, State and Provincial Police: A Study in Police Functioning in the United States and Canada (Evanston, IL, 1941), 6 . 
The paper reconsidered the state police issue in 1927. The editors asked C. L. White, managing editor of the Pennsylvania Farmer, to describe the Pennsylvania State Police's success in reducing farm thefts. White's description was unequivocally enthusiastic - rapturously so. Despite his glowing report, however, the editors of Wallaces' Farmer retained their previous ambivalence about state police. They reminded their readers that state police had misused their power in the past; the Pennsylvania State Police themselves had been "brutal and far from impartial in handling crowds during the steel strike in Pennsylvania."13 Wallace and Drips never again brought up the state police option. Apparently they were unable to surmount their deep-seated reservations, so they allowed the idea to languish.

In the meantime, the paper had adopted a more attractive solution. It involved the volunteerism and the local autonomy that both Wallace and Drips cherished. It also promised an effective means of battling the rural "crime wave" they had identified.

IN 1924 William E. Drips assumed the major responsibility for Wallaces' Farmer's crusade against rural crime as Wallace turned to other concerns, especially his Hi-Bred Corn Company. ${ }^{14} \mathrm{Al}-$ though Wallace doubtless retained a concern for rural crime, he left Drips to pursue the paper's crusade, which increasingly focused on the problem of farm theft.

Under Drips's leadership, vigilantism, in the guise of protective associations, became the solution of choice for Wallaces' Farmer. On May 9, 1924, Drips wrote that the Service Bureau was aware of the existence of protective associations and would like to learn more about them. "If your protective association has been making a good record in checking thievery, we wish you would write in and tell us how it was done."15

13. Wallaces' Farmer, 21 January 1927.

14. See William L. Brown, "H. A. Wallace and the Development of Hybrid Seed Corn," Annals of lowa 47 (Fall 1983), 173. Wallace also returned his attention to agricultural economics. See Donald R. Murphy, "Wallaces' Farmer," Palimpsest 37 (September 1956), 473; Kirkendall, "Wallace's Turn Toward the New Deal," 221-39; Sillars, "Wallace's Editorials," 132-40; Schapsmeier and Schapsmeier, "Prophet in Politics," 8. See also Lauren Soth, "Henry Wallace and the Farm Crisis of the 1920s and 1930s," Annals of lowa 47 (Fall 1983), 199.

15. Wallaces' Farmer, 9 May 1924. 
By the end of the year, Drips had accumulated all the evidence he needed, and he threw himself vigorously into his anticrime campaign. On December 5, 1924, the front page carried the banner headline: "GETTING RID OF THE SNEAK THIEF: How the Vigilantes of Pioneer Days Put Down Horse Thieves and Bandits." A summary of the article placed within a box read, "Stop Thiefl" Drips wanted no one to miss this story. He had no doubt about the cause of the sudden increase in farm thefts. "Since the day of hard roads and the motor truck has come," he wrote, "farmers have suffered greatly from organized thievery." Equally certain of the solution, Drips asked, "How can these depredations be checked?" He found the answer in "the early history of the vigilante associations of the middle-west . . . and in the work of local protective associations. ${ }^{16}$

The entire front page and most of the eleventh in the December 5 issue contained a detailed description of the formation and operation of past lowa vigilante groups. The article carefully depicted a positive image of extra-jurisdictional law enforcement, o giving highest praise to the Anti-Horse Thief Association (AHTA), which was portrayed as more law-abiding than the vigilante associations and as "a valuable aid to the officers of the law." The paper was so impressed with the AHTA that two weeks later it devoted one entire page and half of another to it. W. W. Graves, editor of the AHTA Weekly News, contributed a detailed article describing how similar organizations could be established. Wallaces' Farmer had reached its first conclusion in the fight against farm theft: crime-fighting worked best when it was a voluntary, community-service activity. ${ }^{17}$

During the winter of 1924-25 Drips urged Iowans to establish protective associations of their own. The inadequacies of Iowa's rural law enforcement officers, he claimed, made protective associations necessary. "Maybe it's politics and maybe it isn't," he wrote, "but many farm communities found a complaint

16. Wallaces' Farmer, 5 December 1924. The prominent placement of the articles doubtless had Wallace's approval. Wallace wrote 60 percent of the paper's editorials and approved 100 percent of them. Sillars, "Wallace's Editorials," 132, recounts Wallace's close supervision of his family newspaper; a major policy decision such as this would have been possible only with his direct participation.

17. Wallaces' Farmer, 19 December 1924. 
about a dozen chickens that had been stolen was a good joke to law officers." Increased efforts were needed. Near Iowa Falls a farmer reported the theft of a flock of chickens. A farmer near Alta had hogs stolen. Portland Township in Kossuth County reported a "rash of thefts" in their vicinity. ${ }^{18}$

The formation of vigilance committees in many of the state's rural areas pleased the editor. Kossuth County was among the first. Its protective association had been operating since the autumn of 1922, when seventy-five farmers met at a Farm Bureau meeting and in less than a half-hour raised more than one thousand dollars for a reward fund. The president, vice-president, and secretary of the local Farm Bureau organization served as the officers of the protective association as well. Delaware County followed the same model, while adding an innovation: an advertisement in the local newspaper warning potential thieves away from the county. ${ }^{19}$

During the final months of 1924, Cherokee, Crawford, - Humboldt, Muscatine, Polk, and Scott counties reported the formation of protective associations. Rather than preach at its readers, the paper let an association member from Kossuth County sum up its position: "Organize a local vigilance committee. If you can get fifty men to act then you won't have to worry the local sheriff until you have the man."20

The same article highlighted another benefit of establishing protective associations. Tama County informants reported that following the creation of a Poultry (protective) Association in October 1924, local law enforcement authorities greatly increased their efforts to prevent farm thefts. They did so, the article implied, in the hope of earning the association's rewards. ${ }^{21}$

By 1925, then, the principal elements of Wallaces' Farmer's crime-fighting program were in place. All of the organizations it praised were voluntary. Many of the officers of the protective associations were farmers who already had leadership experience in their local Farm Bureau organizations. At least one countyTama - had taken pains to prevent thefts by warning off poten-

18. Wallaces' Farmer, 16 January 1925.

19. Ibid.

20. Ibid.

21. Ibid. 
tial thieves. Finally, local lawmen were becoming more aware of the seriousness of the farm theft problem.

THROUGHOUT THE YEAR the farm journal continued to encourage farmers to establish protective associations. December was an especially active month, with each of the weekly issues carrying articles about farm theft. In that month Drips began an ingenious four-part fictional series about protective associations. He designed the articles to present the paper's program in an entertaining and familiar format. The story detailed how a fictional rural Iowa community organized, financed, recruited, trained, and advertised their protective association. ${ }^{22}$

In another Service Bureau story Drips exposed private detectives who were proposing to charge an annual fee to protect farmsteads from thieves. He doubted their ability to make good on their promise and pointed back to the journal's solution. "If one hundred farmers would pay one dollar apiece to a local protective association, they would have a dandy sum to offer for rewards." Drips reminded subscribers that "we believe the local protective association idea is the best," and added, "we will be glad to help you organize one. ${ }^{\text {"23 }}$

In January 1927 Drips announced the creation of an Iowa protective association that owed its origin to the direct participation of Wallaces' Farmer. To aid those who wished to begin a protective association, the paper had sent its employees into the country to canvass farmers and to get them interested and enrolled in the new association. According to Drips, "their meeting was a fine example of what farmers can do to protect themselves and enjoy a good time thru [sic] association." 24

Extensive coverage of farm thievery developments continued into the early spring of 1927. Drips noted that sixty-six of Iowa's ninety-nine counties had established protective associations. They had paid rewards totaling more than one thousand dollars statewide. Photographs of reward recipients continued to appear regularly in the paper's Service Bureau column. Drips collected constitutions from several protective associations and

22. Wallaces' Farmer, 4, 11, 18, 25 December 1925, 1, 8 January 1926.

23. Wallaces' Farmer, 3 April, 8 May 1925.

24. Wallaces' Farmer, 21 January 1927. 
made them available to anyone who wished to form an association of their own. He even went so far as to reprint a verbatim copy of one association's promissory note for easy imitation by interested Iowans. The Service Bureau also advised marking poultry as a valuable innovation in keeping track of stolen birds. ${ }^{25}$

NO LONGER CONTENT merely to report on rural crime and encourage farmers to form protective associations as a solution to the problem of farm theft, in the summer of 1926 Wallaces' Farmer announced its direct participation in the crusade against rural crime. The paper's headline on June 25 proclaimed, "STOP FARM THIEVERY! Capture a Thief and Get a Reward!"26

Pugnacity marked the tenor of the announcement. Things were out of hand. One northeastern lowa woman who lived alone had been accosted. Two men came to her home one night. While one covered her with a revolver and kept her indoors, the other loaded her poultry on a truck and drove away. In southern Iowa a large apiary was destroyed and its honey stolen. Harnesses had been stolen. A farm family had been burglarized while attending a funeral. And this was just a sampling. It was timepast time - for farmers to fight back. "The bankers of Iowa have organized their vigilance committees. . . merchants of Iowa have hired detectives. . . now comes the farmer," the paper said. "What can be done? Can not the law officers catch the thieves? Well, Wallaces' Farmer believes they can - if proper incentive is given to work on the cases. If it's worth a hundred dollars to catch a bank bandit we believe it's worth as much to capture the pilferer of a widow's hen house or a farmer's hog lot."27

After this outburst, the paper became even more directly and prominently involved in fighting farm theft. The answer to the problem, its editors concluded, was to provide greater rewards. To encourage lawmen and citizens to catch farm thieves, the farm paper created a reward fund of its own: "Ten one hundred dollar rewards are waiting for the first ten captures of farm thieves." After five years of reporting and discussing the farm

25. Wallaces' Farmer, 18, 25 March 1927, 2 April, 21 May, 4 June 1926.

26. Wallaces' Farmer, 25 June 1926.

27. Ibid. 
thievery predicament, the paper was entering the fray with its own money. ${ }^{28}$

Ever mindful of possible circulation benefits, the journal set six conditions for collecting the reward money. The reward applied only to thefts from Wallaces' Farmer Service Bureau members living in Iowa. In order to collect, the member had to have had a Service Bureau sign displayed at the entrance to the farm at the time of the theft. Rewards were for convictions, not apprehension - the accused person had to go to jail before the reward would be paid - and were available only for the first ten convictions. If a dispute arose regarding reward eligibility, the decision of the local sheriff would govern. Once a trial date was set by a judge, the claimant had to contact the paper with the date. An added incentive concluded the article. The paper promised to pay a reward regardless of any others offered or collected. This allowed a claimant to gather multiple rewards for a single incident. ${ }^{29}$

The paper also began a new policy that winter directed at rural lawmen. It stopped chastising them and began praising them instead. Sheriff Paul T. Beardsley, who had captured "Chicken" Wilson and "Whitey" Lime in Woodbury County, was the first to receive the editors' applause. Sheriff Beardsley warranted so much attention from Drips not only because he subscribed to the paper's program, but also because he had created an innovation that Drips wanted to share. Beardsley seems to have been the first Iowa sheriff to see the enforcement potential of telephones. Rather than personally responding to a complaint of farm theft, the sheriff used the telephone to contact his closest association member. The Woodbury County Sheriff, Drips said, "has a man on the job practically as soon as this case is reported, and in this manner has been able to catch the thieves in every case. ${ }^{\prime 30}$

28. Ibid.

29. Ibid.

30. Wallaces' Farmer, 25 February 1927. See also Roy Alden Atwood, "Interlocking Newspaper and Telephone Company Directorates in Southeastern Iowa, 1900-1917," Annals of lowa 47 (Winter 1984), 256-57; and idem, "The Rural Press and the Electronic Mythos: Images and Interlocking Interests in Southeastern lowa, 1900-1917," Joumalism History 10 (Spring/Summer 1983), 18. Atwood remarks that by 1917 lowa led the nation in the total number of telephone companies, with 5,223; and over 86 percent of rural households had at least one telephone, also the highest percentage in the nation. 
Putting the sheriff's photograph in the paper was a strong message - one no Iowa sheriff (an elected official) could miss. Free publicity was available to other sheriffs who pleased Wallaces' Farmer and supported its program. When Audubon County authorities caught some cattle rustlers, ex-sheriff William Northrup received Drips's commendation and a twenty-fivedollar reward for capturing rustlers who had stolen from a Service Bureau member. Asked his opinion of the paper's campaign "to make stealing a dangerous proposition," Northrup replied, "This thievery campaign of Wallaces' Farmer is a move in the right direction." ${ }^{31}$

Confident of its expertise, Wallaces' Farmer began in 1927 to agitate for new state legislation to "help keep farm property where it belongs." The journal called for laws requiring poultry buyers to obtain a business license. A second law would have required dealers to maintain records of each purchase. These laws were designed to reduce thieves' incentive to steal by making dealers more scrupulous about their poultry purchases. Poultry, once stolen, would likewise be easier to trace, and that would help authorities catch the thieves. ${ }^{32}$

The paper's efforts began to influence state authorities. Drips adivsed his readers in February that Representative Raymond Johnson of Keokuk County had introduced the "Poultry Dealers License Bill" into the Iowa legislature. By mentioning the politician's name in the article, Drips showed that he understood the value of giving free publicity to elected officials other than sheriffs who supported the paper's plan. The "chicken law," which passed the Iowa legislature that spring, assigned administration and enforcement to the state Agriculture Department, which already had inspectors who "can take care of the work." Drips and Wallace were so pleased with the "chicken law" that they included the complete text of it in the paper. ${ }^{33}$

The paper continued to report on the campaign against farm theft during that spring and summer. Drips commended more Iowa sheriffs, and he did not miss an opportunity to remind

31. Wallaces' Farmer, 4 March 1927.

32. Wallaces' Farmer, 14 January 1927.

33. Wallaces' Farmer, 4 February, 15 April 1927. 
readers of the value of being a Service Bureau member. When farmer Mart Miller found all the tires of his automobile missing, he called Adams County Sheriff Clarence Rubin on the telephone and said, "I'm a member of Wallaces' Farmer Service Bureau, and they offer a fifty-dollar reward in a case like this. If you get those tires and soak the thief who took 'em, and the Service Bureau doesn't make good, I will." Drips reported on several other Service Bureau members who received the paper's reward during the summer. Many of the summer's stories carried prison "mug shot" photographs of the thieves. ${ }^{34}$

Drips presented the complete Wallaces' Farmer program in a story at the end of the summer of 1927. He recommended, first, that farmers buy or make burglar alarms for their out-buildings. The paper would furnish free of charge suitable plans to construct an inexpensive alarm. Poultry marking was the second point: a simple dye marker was available to members free of charge from the paper. Drips next advised that farmers keep an accurate running count of their poultry flocks "so you can check them up." If property of any type was stolen, the local sheriff should be notified immediately. Quick contact with the nearest poultry buyer following chicken thefts was also essential. But local volunteer protective associations remained the keystone of the paper's campaign against farm theft. ${ }^{35}$

THE CLIMAX of Wallaces' Farmer's campaign came when a new farm-theft law went into effect in the autumn of 1927. The new law designated the theft of any farm property - regardless of its actual value - as grand larceny. The paper's editors felt a deep sense of satisfaction. They had successfully joined with farmers to reduce farm theft. Wallace and Drips were so confident of the success of their "war against crime" that they extended their protection to include victims of any type of swindle. ${ }^{36}$

By the end of 1927, the character of the journal's anti-crime program was fully defined, and it continued to be a significant activity in succeeding decades. The solution that Henry A. Wallace

34. Wallaces' Farmer, 15 April, 6, 27 May, 3, 10, 17 June, 1, 29 July 1927.

35. Wallaces' Farmer, 25 November 1927. The dye marker was also being recommended in Illinois. See Evans, Prairie Farmer and WLS, 98.

36. Wallaces' Farmer, 2 September 1927, 2 November 1929. 
and William E. Drips pursued was rooted in the state's traditions, and consisted of voluntary, local community-oriented vigilantism. The paper encouraged local lawmen and state politicians to support their approach by rewarding them with free publicity. By decade's end the paper reported its campaign as a continuing success. "We have, we believe, rendered a big service to lowa farmers. We will continue this and will try and push harder our efforts to get the thief for plying his nefarious trade of stealing chickens, livestock, and other farm property." ${ }^{37}$

Wallaces' Farmer continued to pursue its campaign against theft until after World War II. Whether it was as successful as the editors believed is questionable. By pursuing their program, the editors surely increased public awareness of the farm thievery problem, and at the end of the decade some rural sheriffs, perhaps because of the reward and publicity potential, were demonstrably more responsive to farm theft cases than they had been at the beginning of the decade. There was a reduction in the misdemeanor conviction rates reported by the state after 1927. It is impossible, however, to determine whether that reduction can be directly attributed to the paper's activities. What is certain is that farm theft was a problem in lowa during the 1920s and that Wallaces' Farmer actively combatted it.

37. Wallaces' Farmer, 2 November 1929. 
Copyright of Annals of Iowa is the property of State of Iowa, by \& through the State Historical Society of Iowa and its content may not be copied or emailed to multiple sites or posted to a listserv without the copyright holder's express written permission. However, users may print, download, or email articles for individual use. 